\title{
KARYOLOGICAL STUDY OF GENUS BASSIA ALL. IN BULGARIA
}

\author{
N. Grozeva*, S. Gospodinova
}

Faculty of Agriculture, Trakia University, Stara Zagora, Bulgaria

\begin{abstract}
The karyotype morphology of four species of Bassia All. - B. hirsuta (L.) Asch., B. laniflora (S. G. Gmel) A. J. Scott., B. prostrata (L.) Beck, B. scoparia (L.) A. J. Scott is reported for the first time from Bulgarian populations. The karyograms and the idiograms of all studied populations were illustrated. The somatic chromosome numbers for all species were the same $(2 n=18)$. The karyotypes for all of the investigated populations consist of metacentric and submetacentric chromosomes and in the two of the studied populations of B. hirsuta were established chromosomes with satellites.
\end{abstract}

Key words: Bassia, karyotype, chromosome number

\section{INTRODUCTION}

Kochia Roth and Bassia All. are shrubs, subshrubs or herbs with indehiscent fruits, and with embryos that are horizontally oriented in the flower and ring-like rather than spiral (1). Scott (2) on the basis of structure of the perianth proposed to submerge Kochia into Bassia. The molecular analysis of Kadereit \& Freitag (3) confirmed its justification. In Bulgarian flora genus Bassia is represented by 4 species: Bassia hirsuta (L.) Asch., Bassia laniflora (S. G. Gmel) A. J. Scott. (= Kochia laniflora Borbás), Bassia prostrata (L.) Beck (= Kochia prostrata (L.) Schrad.), Bassia scoparia (L.) A. J. Scott (= Kochia scoparia (L.) Schrad.) (4-6).

B. hirsuta occurs on saline sands and clay soils along the Black Sea coast and the shores of saline lakes at the Black Sea coast, rarely on rocks facing the sea $(4,6-8)$. The species is protected under the Biological Diversity Act (9) and is included in the Red Book of Bulgaria under the category „Endangered“ (8).

$B$. laniflora inhabits sandy terrains by the sea and along inland rivers (7). The species has been reported for the Black sea coast, Danube plain and Struma valley $(4,6)$.

B. prostrata grows on dry rocky, stony and sandy terrains on the sea coast as well as on

\footnotetext{
*Correspondence to: Neli Grozeva, e-mail: grozeva@uni-sz.bg, +35942699 317, Faculty of Agriculture, Trakia University, 6000 Stara Zagora, Bulgaria
}

dry and sunny rocky, stony and sandy soils, mainly by the Danube river, Black sea coast and the Danube plain (4, 6-7).

B. scoparia is adventitious species (6). It is cultivated in the country, grows near villages and by roads in ruderalized areas, very often appears as crop weed $(4,7)$.

The present study is a part of a multi-annual research on family Chenopodiaceae within the Bulgarian flora and aims to investigate the chromosome number and karyotype morphology of taxa from Bassia in Bulgaria, thus to help in taking taxonomic decisions and elucidate evolutionary problems.

\section{MATERIALS AND METHODS}

Karyological analyses were carried out on 6 natural Bulgarian populations of the genus Bassia, referred to four species (Table 1). Chromosome numbers and karyotypes have been reported on lasting preparations of metaphase root apex plates of seeds germinated in laboratory conditions collected in the natural habitats of the species. The root tips were treated and squashed according to the accepted methods (10). The chromosomal type was determined after the centromere index $\mathrm{I}=$ $\mathrm{s} / \mathrm{s}+\mathrm{l}$ (in\%), according to the classification proposed by GRIF and AGAPOVA (11). The idiograms are constructed after measurements were performed on three metaphase plates from each population. The voucher specimens are kept in the herbarium of the Bulgarian Academy of Sciences (SOM). 
Table 1. Studied populations of genus Bassia All.

\begin{tabular}{|c|c|c|}
\hline Species & $\begin{array}{l}\text { Population location } \\
\end{array}$ & $2 n$ \\
\hline \multirow[t]{3}{*}{ Bassia hirsuta } & $\begin{array}{l}\text { Northern Black Sea Coast, Varnensko lake, periodically flooded } \\
\text { coastal alluvial, at } 79 \mathrm{~m}, 43^{\circ} 11,09^{\prime} \mathrm{N}, 27^{\circ} 50,16^{\prime} \mathrm{E} \text {. }\end{array}$ & $18^{*}$ \\
\hline & $\begin{array}{l}\text { Southern Black Sea Coast, Atanasovsko lake, at the northern end } \\
\text { of the lake near the road Burgas - Pomorie at } 1.5 \mathrm{~m}, 42^{\circ} 35,14{ }^{\prime} \mathrm{N} \text {, } \\
27^{\circ} 36,07^{\prime} \mathrm{E} \text {. }\end{array}$ & $18^{*}$ \\
\hline & $\begin{array}{l}\text { Southern Black Sea Coast, Pomoriysko lake, sandy terrains near } \\
\text { Salt museum, at } 1-2 \mathrm{~m}, 42^{\circ} 35,14^{`} \mathrm{~N}, 27^{\circ} 36,07^{`} \mathrm{E} \text {. }\end{array}$ & $18^{*}$ \\
\hline Bassia laniflora & $\begin{array}{l}\text { Southern Black Sea Coast, Ahtopol town, near the coastline south } \\
\text { of the town, at } 5 \mathrm{~m}, 42^{\circ} 05^{\prime} 40^{\prime \prime} \mathrm{N} 27^{\circ} 56^{\prime} 60^{\prime \prime} \mathrm{E} \text {. }\end{array}$ & $18^{* *}$ \\
\hline Bassia prostrata & $\begin{array}{l}\text { Thracian Lowland, Rakitnitsa village, ruderal places, at } 184 \mathrm{~m} \text {, } \\
42^{\circ} 20^{\prime} 36^{\prime \prime} \mathrm{N}, 25^{\circ} 31^{\prime} 15^{\prime \prime} \mathrm{E} \text {. }\end{array}$ & $18 * * *$ \\
\hline Bassia scoparia & $\begin{array}{l}\text { Thracian Lowland, Tselina village, ruderal places, at } 193 \mathrm{~m}, 42^{\circ} \\
07^{\prime} 14^{\prime \prime} \mathrm{N}, 25^{\circ} 27^{\prime} 06^{\prime \prime} \mathrm{E} \text {. }\end{array}$ & $18 * * *$ \\
\hline
\end{tabular}

\section{RESULTS AND DISCUSSIONS}

Bassia hirsuta

For the three studied populations of the species are established diploid chromosome number of $2 n=18$ (Table 1, Figure 1). Among the total of 9 pair chromosomes, 5 pairs are metacentric and 4 pairs are submetacentric. Two of the populations, from Varnenskoto and Atanasovskoto Lake, have satellites.

The total haploid chromosome length for the population from Varnenskoto Lake is $20.23 \mu$
(Figure 1A). The longest chromosome has the length of $4.05 \mu$ and is submetacentric with satellites and the shortest one has the length of $1.6 \mu$ and is metacentric. The length of long arm of chromosomes is between 0.84 and 2.12 $\mu$ and the length of short arm of chromosomes is between 0.51 and $1.93 \mu$. The karyotype formula is as $2 n=10 \mathrm{~m}+6 \mathrm{sm}+2 \mathrm{sm}-\mathrm{SAT}$. The ideogram of chromosomes is illustrated in Figure1B.

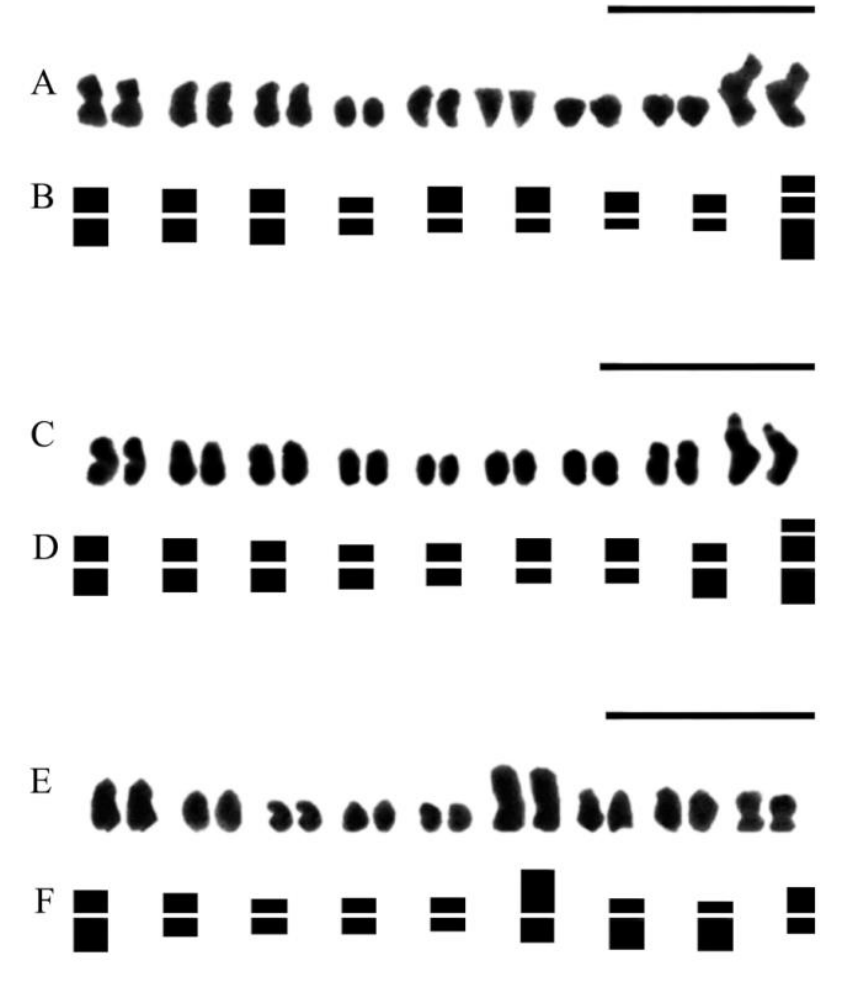

Figure 1. Karyograms and idiograms of Bassia hirsuta (L.) Asch. populations from: A-B Varnensko Lake; C-D Atanasovsko Lake; E-F Pomoriysko Lake. 
The total haploid chromosome length for the population from Atanasovskoto Lake is 19.16 $\mu$ (Figure 1C). The longest chromosome has the length of $3.29 \mu$ and is submetacentric with satellites and the shortest one has the length of $1.6 \mu$ and is metacentric. The length of long arm of chromosomes is between 0.82 and 1.83 $\mu$ and the length of short arm of chromosomes is between 0.56 and $1.45 \mu$. The karyotype formula is as $2 n=10 m+6 s m+2 s m-S A T$. The ideogram of chromosomes is illustrated in Figure 1D.

The total haploid chromosome length for the population from Pomorie Lake is $19.73 \mu$ (Figure 1E). The longest chromosome has the length of $3.38 \mu$ and is submetacentric and the shortest one has the length of $1.53 \mu$ and is metacentric. The length of long arm of chromosomes is between 0.78 and $2.05 \mu$ and the length of short arm of chromosomes is between 0.66 and $1.33 \mu$. The karyotype formula is as $2 n=10 \mathrm{~m}+8 \mathrm{sm}$. The ideogram of chromosomes is illustrated in Figure 1F.

The karyotype morphology of the species is reported for the first time from Bulgarian populations. The chromosome number $2 n=18$ confirms the previous results from Bulgaria -
GROZEVA N, et al.

Northern Black Sea Coast, Schablensko Lake and Southern Black Sea Coast, Poda Protected Area (12). The results obtained correspond also to the data reported by the other authors (15-18).

\section{Bassia laniflora}

For the studied population of the species is established chromosome number of $2 n=18$ (Table 1, Figure 2A). Among the total of 9 pair chromosomes of this population, 5 pairs are metacentric and 4 pairs are submetacentric. The total haploid chromosome length is 14.88 $\mu$. The longest chromosome has the length of $2.37 \mu$ and is metacentric and the shortest one has the length of $1.21 \mu$ and is submetacentric. The length of long arm of chromosomes is between 0.68 and $1.44 \mu$ and the length of short arm of chromosome is between 0.34 and $1.08 \mu$. The karyotype formula is as $2 n=10 \mathrm{~m}+$ $8 \mathrm{sm}$. The ideogram of chromosomes is illustrated in Figure 2B.

The karyotype morphology of the species is reported for the first time from Bulgarian populations. The diploid chromosome number of $B$. laniflora is in accordance with earlier countings (19-21).

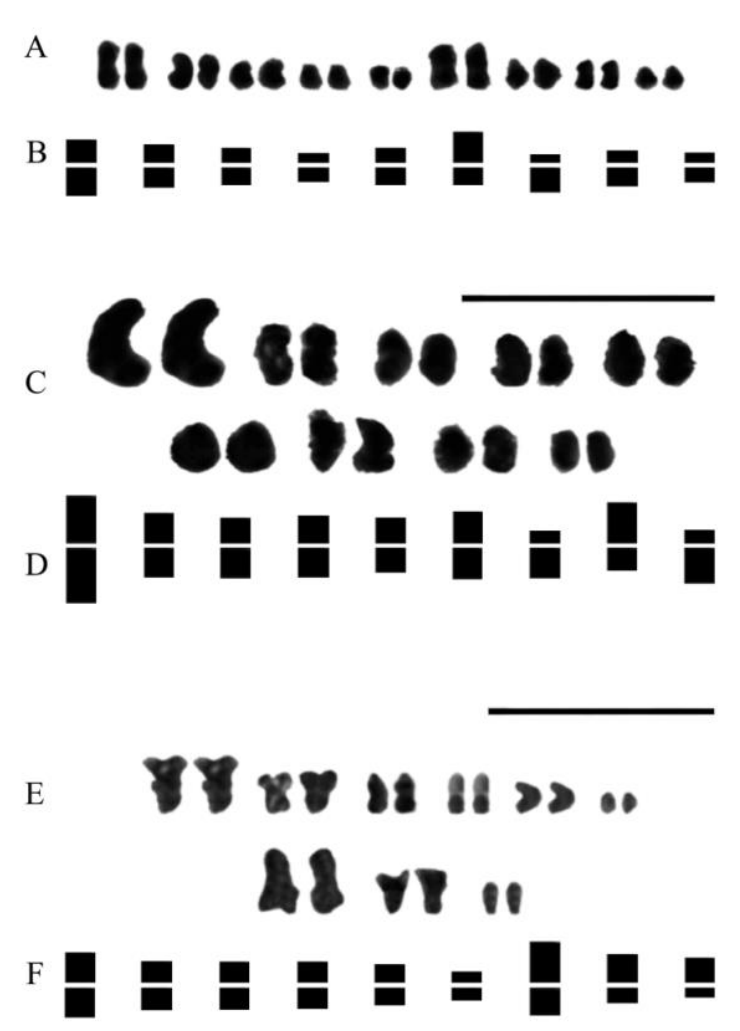

Figure 2. Karyograms and idiograms of populations of: A-B Bassia laniflora (S. G. Gmel) A. J. Scott. from Ahtopol town; C-D Bassia prostrata (L.) Beck from Rakitnitsa village; E-F Bassia scoparia (L.) A. J. Scott from Tselina village. 


\section{Bassia prostrata}

For the studied population of the species is established diploid chromosome number of $2 n$ $=18$ (Table 1, Figure 2C). Among the total of 9 pair chromosomes of this population, 6 pairs are metacentric and 3 pairs are submetacentric. The total haploid chromosome length is 25.43 $\mu$. The longest chromosome has the length of $4.33 \mu$ and is metacentric and the shortest one has the length of $2.12 \mu$ and is submetacentric. The length of long arm of chromosomes is between 1.39 and $2.41 \mu$ and the length of short arm of chromosome is between 0.65 and $1.92 \mu$. The karyotype formula is as $2 n=12 \mathrm{~m}+$ $6 \mathrm{sm}$. The ideogram of chromosomes is illustrated in Figure 2D.

The karyotype morphology of the species is reported for the first time from Bulgarian populations. The diploid chromosome number $2 n=18$ reported here agrees with reports of Pope \& McArthur (22), Javưrková-Jarolímová (23), Lomonosova \& Krasnikov (24), Stepanov (25), Zakirova (26), Krasnikov (27). Some other chromosome numbers were also reported for the same species: $n=8$ (28), $2 n=36$ (29$30)$ and $2 n=54$ (29).

\section{Bassia scoparia}

For the studied population of the species is established diploid chromosome number of $2 n$ $=18$ (Table 1, Figure 2E). Among the total of 9 pair chromosomes of this population, 7 pairs are metacentric and 2 pairs are submetacentric. The total haploid chromosome length is 18.09 $\mu$. The longest chromosome has the length of $3.09 \mu$ and is metacentric and the shortest one has the length of $1.08 \mu$ and is metacentric, too. The length of long arm of chromosomes is between 0.62 and $1.72 \mu$ and the length of short arm of chromosome is between 0.37 and $1.37 \mu$. The karyotype formula is as $2 n=14 \mathrm{~m}+$ $4 \mathrm{sm}$. The ideogram of chromosomes is illustrated in Figure 2F.

The karyotype morphology of the species is reported for the first time from Bulgarian populations. The chromosome number $2 n=18$ confirms the previous result from Bulgaria, Thracian Lowland, Plovdiv Botanical Garden (31). It confirms the earlier counts published from elsewhere $(24,27,30,32-37)$.

\section{CONCLUSIONS}

The chromosome numbers established from Bulgarian populations of $B$. hirsuta, $B$. laniflora, B. prostrata and B. scoparia are diploid based on basic chromosome number $\mathrm{x}$ $=9$. The karyotypes for all of the investigated populations consist of metacentric and submetacentric chromosomes and in the two of the studied populations of $B$. hirsuta were established chromosomes with satellites.

The total haploid chromosome length of the studied populations of $B$. hirsuta is between 19.16 and $20.23 \mu$ and the chromosome length ranges from 1.53 to $4.05 \mu$.

The total haploid chromosome length of $B$. laniflora is $14.88 \mu$ and the chromosome length ranges from 1.21 to $2.37 \mu$.

The total haploid chromosome length of $B$. prostrata is $25.43 \mu$ and the chromosome length ranges from 2.12 to $4.33 \mu$.

The total haploid chromosome length of $B$. scoparia is $18.09 \mu$ and the chromosome length ranges from 1.08 to $3.09 \mu$.

The karyotype morphology of fourth species from genus Bassia is reported for the first time from Bulgarian populations.

\section{REFERENCES}

1. Ge-Lin Chu and S. C. Sanderson, The genus Kochia (Chenopodiaceae) in North America. Madrono, 55(4): 251-256, 2008.

2. Scott, A. J., A revision of the Camphorosmioideae (Chenopodiaceae). Feddes Repertorium, 89:101-119, 1978.

3. Kadereit, G. and Freitag, H., Molecular phylogeny of Camphorosmeae (Camphorosmoideae, Chenopodiaceae): Implications for biogeography, evolution of C4-photosynthesis and taxonomy. Taxon, 60 (1), 51-78, 2011.

4. Delipavlov, D., Cheshmedzhiev, I. (eds), Key to the Plants of Bulgaria. Acad. Press Agrarian University, Plovdiv, 2003 (Bg).

5. Uotila, P., Bassia All. (pro parte majore). In: Euro+Med Plantbase - the information resource for Euro-Mediterranean plant diversity, 2011.

http://ww2.bgbm.org/EuroPlusMed/Regional Taxon.asp?PTNameFK=17688\&PTRefFk=73 $00000 \&$ Name $=$ Bassia $($ accessed 18.11.2015).

6. Assyov, B., Petrova, A. (eds), Conspectus of the Bulgarian Vascular Flora. Distribution Maps and Floristic Elements. Fourth revised and enlarged edition. Bulgarian Biodiversity Foundation, Sofia (Bg), 2012.

7. Yordanov, D., Kozhuharov, B., Bassia All. Kochia Roth. In: Yordanov, D. (ed.), Flora Reipublicae Bulgaricae, vol. 3, Editio Acad. „Prof. Marin Drinov”, Serdicae (in Bulgarian), pp 557-561, 1966.

8. Stoeva, M., Bassia hirsuta (L.) Ash.. In: Peev, D. et all. (eds), Red Data Book of the Republic of Bulgaria. Volume 1. Plants and Fungi. BAS \& MoEW, Sofia, pp 416, 2015.

9. Biological Diversity Act, Darzhaven Vestnik no. 77 from 9 August 2002, pp. 9-42. 
Amended in Darzhaven Vestnik no. 94 from 16 November 2007, 2002 (Bg).

10. Grozeva, N., C. pumilio (Chenopodiaceae): a new species to the Bulgarian flora. Phytol. Balkan., 13(3): 331-334, 2007.

11. Grif, G. and Agapova, P., The methods of description of plant karyotypes. Botanichesky Zhurnal, 71: 550-553, 1986.

12. Grozeva, N. and Todorova, M., Karyological and morphological variations within Bassia hirsuta (L.) Asch. in Bulgaria". Trakya University Journal of Natural Sciences, 15(1): 17-23, 2014.

13. Grozeva, N., IAOP/IOPB Chromosome data 16. - In: Marhold K. IAOP/IOPB column. Taxon, 62(3): 1356, E2-E4. http://www.iopb.org/PDF/IAPT_IOPB_Chr_d ata16.pdf, 2013.

14. Grozeva, N. Reports 1852-1858. In: Kamari, G., Blanche, C. \& Siljak-Yakovlev, S. (eds): Mediterranean chromosome number reports 25. Flora Mediterranea, 25: 150-156. 2015.

15. Winge, O., Studier over planterigets chromosomtal of chromosomernes betydning. Meddelelser Carisberg, Laboratoriet, 13: 127-267, 1917.

16. Wulff, H. Karyologische Untersuchungen an der Halophytenflora Schleswig. Holsteus Jahrb. Wissensch.Bot. 84(5): 812-840, 1937.

17.Zakharyeva, O., Chisla khromosom nekotorjie tsvetkovykh rasteniy Kavkaza i Srednei Asii. Bot. Zhurn., SSSR, 70(12): 1699-1701, 1985.

18. Lomonosova, M. N., Chromosome numbers of Chenopodiaceae species from Russia and Kazakhstan. Bot. Žhurn. (Moscow \& Leningrad) 90 (7): 1132-1134, 2005.

19. Vachova, M. and Schwarzova., T., Chenopodiaceae. In Löve, Á. (ed.), IOPB chromosome number reports LXI. Taxon, 27: 375-392, 1978.

20. Vachová, M. and Feráková, V. 1980: Chenopodiaceae. In Löve, Á. (ed.), IOPB Chromosome number reports LXIX. Taxon, 29: 722-723, 1980.

21.Lomonosova, M. N., Krasnikov, A., A. and S. A. Krasnikova, S. A., Chromosome numbers of Chenopodiaceae family members of the Kazakhstan flora. Bot. Žhurn. (Moscow \& Leningrad), 88(2): 134-135, 2003.

22.Pope, C. L. and McArthur, E. D., Chenopodiaceae. In Love, A. (ed.), IOPB chromosome number reports LV. Taxon, 26: 107-109, 1977.

23. Javůrková-Jarolímová, V. In Měsíček, J. \& Javůrková-Jarolímová ,V., List of chromosome Numbers of the Czech Vascular Plants. Academia, Praha, 1992.

24. Lomonosova, M. N., Krasnikov, A. A., Chromosome numbers in some members of the Chenopodiaceae. Bot. Žhurn. (Moscow \& Leningrad), 78 (3): 158-159, 1993.

25. Stepanov, N. V., Chromosome numbers of some higher plants taxa of the flora of Krasnoyarsk region. Bot. Žhurn. (Moscow \& Leningrad), 79 (2): 135-139, 1994.

26.Zakirova, R. O., Chromosome numbers of some Alliaceae, Salicaceae, Polygonaceae, and Chenopodiaceae of the South Balkhash territory. Citologija, 41 (12): 1064, 1999.

27. Krasnikov, A. A., Karyological study of the Tuva Republic flora: a summary.

Turczaninowia, 7 (2): 82-95, 2004.

28. Kaliagin, I. N., Mikrosporogeniz i razvitie muzhskogo gametofita i Kochia prostrata (L.) Schrad. 66-72. In Saidov, D. K. (ed.), Materialy po strukturnym i funktsional'nym osobennostiam poleznykh dikorastushchikh rastenii Uzbekistana, 1970.

29. Lidzhieva, N. Tz. and Erendzhenova, N. E., Cytogenetic assay of cenopopulation of Kochia prostrata in Kalmykia. In the World of Scientific Discoveries v Mire Nauchnykh Otkrytiy. 60 (12.1): 208-220, 2014.

30.Lomonosova, M.N., Shaudo, D. N., Ankova, T. V., Erst, A. S., Smirnov, S. V. and Wang Jian. Chenopodiaceae. In: Marhold, K. (ed.). IAPT/IOPB chromosome data 18. Taxon, 63 (6): E16-E18, 2014.

31.Popova, M. \& Ceschmedjiev, Reports. In Love, A. (ed.), IOPB chromosome number reports LXI. Taxon, 27: 375-392, 1978.

32. Uhrikova, A., In: Majovski \& al. Index to chromosome numbers of Slovakian flora. Part 4. Acta Fac. Rerum Nat. Univ. Comenianae, Bot., 23: 1-23, 1974.

33.Pogan, E., Czapik, R., Jankun, A., Kuta, E. and al., Further studies in chromosome numbers of Polish Angiosperms. Part XV. Acta Biol. Cracov. Ser. Bot. 24: 91-126, 1982.

34. Murín, A. and Svobodová, Z.,. Karyological study of the Slovak flora XXVI. Acta Fac. Rerum Nat. Univ. Comenianae, Bot., 39: 5965, 1992.

35. Kiehn, M., Vitek, E. \& Dobea, C., In C. Dobea \& E. Vitek, Documented Chromosome Number Checklist of Austrian Vascular Plants. Verlag des Naturhistorischen Museums Wien, Vienna, 2000.

36. Probatova, N. S., Chromosome numbers in some plant species from the Razdolnaya (Suifun) river basin (Primorsky Territory). Bot. Žhurn. (Moscow \& Leningrad), 85 (12): 102-107, 2000.

37.Lomonosova, M. N., Chromosome numbers of some Chenopodiaceae representatives of the flora of Russia. Bot. Žhurn. (Moscow \& Leningrad) 91 (11): 1757-1759, 2006. 